\title{
Mineral nutrition evolution in the formation of fruit tree rootstocks and seedlings
}

\author{
William Natale ${ }^{1}$, Antonio João de Lima Neto², Danilo Eduardo Rozane ${ }^{3}$, \\ Léon Etienne Parent ${ }^{4}$, Márcio Cleber de Medeiros Corrêa ${ }^{5}$
}

\begin{abstract}
The importance of mineral nutrition to the various plant species has been recognized for many years. Since nutrients are directly linked to physiological and metabolic processes, they promote the growth of rootstocks and seedlings, contributing to the formation of more productive orchards. As a consequence of the lack of technical information for most fruit trees, fertilization in nurseries has still been carried out empirically, sometimes underestimating or overestimating nutritional requirements and compromising the quality of plants produced. Given the importance of mineral nutrition in the formation of high-quality seedlings and the lack of scientific information on the topic, the aim of the present review was to raise interest in further research, and contribute to produce nutritionally balanced fruit seedlings.
\end{abstract}

Index terms: nurseries, fertilization, nutritional diagnosis.

\section{Evolução da nutrição mineral na formação de porta-enxertos e mudas de frutíferas}

Corresponding author: natale@ufc.br

Received: September 26, 2016 Accepted: May 29, 2017

Copyright: All the contents of this journal, except where otherwise noted, is licensed under a Creative Commons Attribution License.

Resumo - A importância da nutrição mineral para as diversas espécies de plantas é reconhecida há muitos anos. Por estarem diretamente ligados aos processos fisiológicos e metabólicos, os nutrientes favorecem o crescimento de porta-enxertos e mudas, contribuindo para a formação de pomares mais produtivos. Em razão da carência de informações técnicas para a maioria das frutíferas, a fertilização em viveiros ainda é feita de forma empírica, por vezes subestimando ou superestimando as exigências nutricionais e comprometendo a qualidade das plantas produzidas. Tendo em vista a importância da nutrição mineral na formação de mudas com qualidade, bem como a escassez de informações científicas, a presente revisão objetiva despertar o interesse para novas pesquisas, além de contribuir para a produção de mudas de frutíferas nutricionalmente equilibradas. Termos para indexação: viveiros, fertilização, diagnose nutricional. 


\section{Introduction}

The fruit growing activity has increased in the past decades, in both production and productivity. In the early 1960s, the world fruit production was 175 million tons in a cultivated area of 24 million hectares, expanding to 673 million tons in a cultivated area of 56 million hectares in 2013 , which represents production growth of $285 \%$ and an increase in cultivated area of $133 \%$ (FAOSTAT, 2016).

Expansion in cultivation area and orchard renewal demands the growing of millions of seedlings of fruit tree species annually worldwide. To be taken to the field, these seedlings must meet minimum sanitation and quality criteria, taking into account morphological characteristics of plants, such as height, number of leaves and stem diameter. However, no information regarding the nutritional condition of these plants is included in these standards.

Until late 1990s, production of fruit tree rootstocks and seedlings was basically performed in open-air nurseries, using only soil as substrate. Nevertheless, some diseases began to spread from nurseries to the field through seedlings, destroying many farming areas and causing severe losses. This fact made surveillance bodies impose rules, and currently, most seedlings should be produced in netted nurseries.

After the new enforced requirements, rootstock and seedling production underwent several changes, among which the adoption of commercial, inert, pathogen-free substrates stands out. At present, there are substrates with varied chemical composition on the market. The use of tree growth plastic tubes in some situations may result in volume restriction, which may compromise the development of the root system.

Commercial substrates do not meet the nutritional needs of plants, presenting low ion-exchange capacity, which, together with the low volume of tubes, favors nutrient loss through leaching. This problem demands more attention during irrigation and fertilization, and requires more efficient cultivation practices regarding fertilization splitting.

Currently, fertilizers can be marketed as powder, grain and capsules, each of them with specific solubility and nutrient availability. The adoption of these changes in the production process demands new studies to provide information to nurserymen and producers. The aim of the present review was to provide information about the importance of adequate mineral nutrition of rootstocks and seedlings, and guide plant growth with adequate nutritional balance.
Importance of adequate nutrition of rootstocks and seedlings in the establishment of fruit tree orchards - Formation of rootstocks and seedlings is one of the most important steps in the establishment of fruit tree orchards. Growing wellformed seedlings in nurseries allows plants to cope with environmental adverse situations and stress in the field after planting (BARBOSA et al., 2003). Fertilization is indispensable in this initial period, because it promotes the growth and development of rootstocks and seedlings and improves their nutritional status (DIAS et al., 2012; SOUZA et al., 2015), which results in better survival conditions after orchard establishment.

Adequate nutrition of rootstocks and seedlings is an important factor for adequate development and establishment of the culture in the field. Production of adequate nourished rootstocks contributes to the success of orchard exploration and can influence early production, positively impacting the economic return of the capital invested by fruit farmers (ROZANE et al., 2013).

The quality of seedlings is closely related to the amount of nutrients provided for plants. Adequate nutrition guarantees shoot growth and enables better development of the root system and exploration of larger substrate volumes, which contributes to increase water and nutrient absorption. As pointed out by Arouca et al. (2011) and Rozane et al. (2011a) for 'Tahiti' lime and star fruit, respectively, roots are responsible for $30 \%$ and $26 \%$ of total dry matter.

Dry matter accumulation in each plant organ is proportionally related to nutrient accumulation. This fact was observed by Augostinho et al. (2008), who reported that the average accumulation of macronutrients in 'Pedro Sato' guava tree seedlings concentrates in leaves $(65 \%)$, with the remainder distributed in roots (18\%) and stem $(17 \%)$, a result that corroborates the trend observed for dry matter accumulation, with predominance in leaves $(51 \%)$, followed by roots $(25 \%)$ and stem $(24 \%)$. Under nutrient deficiency conditions, root architecture and morphology are affected, which results in lower production of root hairs and reduced growth, facts that reinforce the importance of adequate nutrient supply in the seedling phase for the development of the root system (MEI et al., 2011; CAO et al., 2013).

Nutrient supply, either through substrate or fertilization, is fundamental to meet the needs of rootstocks and seedlings, because nutritional imbalance compromises the growth and development of plants. Negative consequences of malnutrition can interfere with the establishment of orchards, given that rootstocks and seedlings submitted to nutritional deficiency will not present the same performance as those that received adequate nutrition during their formation. Lowquality seedlings will result in poorly formed orchards, compromising the culture exploration and the production 
process as a whole. To keep productive and long-lived orchards, it is necessary to obtain healthy and wellnourished plants (SOUZA et al., 2015).

The current production of fruit tree rootstocks and seedlings involves inert and sterile commercial substrates composed of vermiculite, sand, peat, pine bark or other organic materials. These substrates present proper physical and chemical characteristics and provide nutrients necessary for the development of plants (SCHÄFER et al., 2008). However, the quantity of essential elements present in substrates is usually insufficient for the initial development stage; consequently, fertilization is required to complement nutrient input, so that plants complete their development cycle in nurseries in a shorter period of time. Another aspect that should be considered is that substrates usually present imbalanced nutrient proportions regarding plant demand (DIAS et al., 2012).

The use of high-quality seedlings in the establishment of fruit tree orchards represents $60 \%$ of the success in culture exploration (MINAMI et al., 1994). Thus, the use of farming practices in nurseries, such as balancing the fertilization of substrates, allows the production of vigorous, healthy and uniform and adequate plants for final field planting.

In the establishment of high-quality orchards, the many production steps require nutrient supply in adequate amounts and forms for the culture. In this context, obtaining high-quality rootstocks and seedlings represents an important step in the growth and initial establishment of fruit trees (BRASIL; NASCIMENTO, 2010). Plants in the nursery stage and producing trees, when adequately nourished, have lower susceptibility to be attacked by pests and diseases, showing higher tolerance to environmental stress and exhibiting increased fruit productivity and quality (DIAS et al., 2012).

Adequate nutrition of rootstocks stimulates growth, which increases stem diameter, the characteristic used as reference to perform grafting (ROZANE et al., 2009a; LIMA NETO et al., 2015). Consequently, nutritional balance contributes to reduce the time that nurserymen have to wait to carry out grafting, which leads to shorter stay of plants in nurseries and ultimately lower production cost. On the contrary, when excessive doses of fertilizers are used, a suppressing effect on the development of plants may occur, as reported by Prado et al. (2009) in citrus seedlings. Perin et al. (1999) report that this effect can be attributed to the increased osmotic pressure of the culture medium, causing harm to roots and impairing the absorption of nutrients and development of plants, in addition to other aspects, such as the antagonistic effect among nutrients.

Before field planting, seedlings must be vigorous, with uniform growth, and leaves must exhibit size and color typical of the species. After field planting, highquality seedlings showing adequate nutritional status are less likely to die and have higher probability of showing quick and vigorous growth in the new environment, often leading producers to skip replanting step, increasing the benefit-cost ratio (MENDONÇA et al., 2009).

Nutritional requirements of fruit tree rootstocks and seedlings - The amounts of nutrients to be provided to rootstocks and seedlings at the appropriate time, in adequate doses, taking into account the balance among elements, substrate type and species and cultivar, demand from nurserymen a set of actions to be implemented in the production process. Among these actions, producers have to know the absorption rate and nutrient accumulation in plants at different phenological phases.

Nutrient absorption rate is a reference to fertilize seedlings with adequate doses for satisfactory plant development. Knowledge of the amounts of nutrients absorbed by plants at different phenological phases can help determining the composition of the substrate to be used and plan topdressings for seedlings for the period that plants remain in the nursery (BARBOSA et al., 2003).

Nutrient absorption rate represents the amount of absorbed and accumulated dry matter throughout the cultivation cycle, that is, the amount required by plants, which differs from the amounts that must be applied. The latter takes into consideration the efficiency of use of each nutrient, which varies as a function of several situations to which plants can be submitted to (ROZANE et al., 2013).

The amount of absorbed and accumulated nutrients in seedlings depends on many factors, such as cultivar (AUGOSTINHO et al., 2008; FRANCO et al., 2008a) and rootstock used (ZAMBROSI et al., 2013) in the specific situation, given that rootstocks are responsible for nutrient absorption, which can be selective regarding absorption and transport, resulting in different concentrations of nutrients in leaves (AMIRI et al., 2014; HROTKÓ et al., 2014). It is important to stress that the quantity of nutrients absorbed by plants is related to genetic characteristics of the species, absorption kinetic constants and factors associated with the substrate, such as humidity and concentration of nutrients in solution.

The growth curve and nutrient uptake rate vary among species, within species, and among cultivars (AUGOSTINHO et al., 2008; FRANCO et al., 2008a; FREITAS et al., 2011; ROZANE et al., 2011b). For this reason, it is necessary to emphasize the importance of obtaining these characteristics for each species to determine the nutritional requirements of rootstocks and seedlings as accurately as possible, and develop fertilizer recommendation programs that better suit the needs of plants.

Nutrient uptake rate and fruit tree rootstock and seedling growth show similar behavior for several species. They usually present three phases: first, slow initial growth 
stage takes place; then, growth and nutrient accumulation become intense and reach maximum rate; in the last stage, growth is nearly stable. This behavior is observed in several species and is described by a sigmoid curve (AUGOSTINHO et al., 2008; FREITAS et al., 2011).

In 'Pera' orange seedlings grafted onto 'Taiti' lime plants evaluated over 360 days after emergence (DAE), the total dry matter mass accumulation was slow in the first $90 \mathrm{DAE}$, and was responsible for less than $2 \%$ of the amount collected until the end of the process. This step was followed by a fast increase stage, which lasted until 330 DAE, after which a decrease occurred, followed by a stabilization trend (REZENDE et al., 2010). Nutrient uptake rate in plants followed the same growth and accumulation trend recorded for dry matter mass, and was slow until 90 DAE. Plants accumulated between $0.7 \%$ and $1.6 \%$ of macronutrients and from $0.5 \%$ to $9 \%$ of micronutrients $(\mathrm{Cu}, \mathrm{Fe}, \mathrm{Mn}$ and $\mathrm{Zn})$ until the end of the cycle (REZENDE et al., 2010).
For rangpur lime and 'Swingle' citrumelo rootstocks that had 'Valencia' sweet orange trees as scion, the nutrient uptake rate in citrus seedlings followed plant dry matter mass growth and accumulation, and was slow until 35 days after transplanting (DAT). However, nutrient accumulation in seedlings varied according to fertilizer management (BATAGLIA et al., 2005), pointing to the importance of nutrient specificities for each cultivar.

Nutrient accumulation in rootstocks and seedlings presents variations that prevent the meeting of adequate nutritional needs of seedlings, because there is no research about the nutrient uptake rate of many commercial species. Given the need for this information, the present review evaluated the amounts of macro (Table 1) and micronutrients (Table 2) accumulated by rootstocks and seedlings of some fruit tree species.

Table 1. Amount of macronutrients accumulated in rootstocks and seedlings of different species.

\begin{tabular}{|c|c|c|c|c|c|c|}
\hline $\mathbf{N}$ & $\mathbf{P}$ & $\mathbf{K}$ & $\mathbf{C a}$ & Mg & $\mathbf{S}$ & Reference \\
\hline & 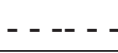 & - & $---g$ & --- & -- & \\
\hline \multicolumn{7}{|c|}{ CITRUS } \\
\hline 1.918 & 0.352 & 1.322 & 1.509 & 0.291 & 0.205 & Rezende et al. (2010) ${ }^{1 /}$ \\
\hline 0.153 & 0.015 & 0.844 & 0.079 & 0.013 & 0.003 & Tecchio et al. (2006) \\
\hline \multicolumn{7}{|c|}{ STAR FRUIT TREE } \\
\hline 1.058 & 0.159 & 0.871 & 0.347 & 0.123 & 0.147 & Freitas et al. (2011) ${ }^{3}$ \\
\hline 1.423 & 0.163 & 0.943 & 0.447 & 0.243 & 0.166 & Rozane et al. (2011b) \\
\hline 1.378 & 0.177 & 0.913 & 0.430 & 0.241 & 0.175 & Rozane et al. (2011b) $\frac{5}{6}$ \\
\hline 0.634 & 0.088 & 0.368 & 0.152 & 0.106 & 0.098 & Rozane et al. (2013) 6 \\
\hline \multicolumn{7}{|c|}{ GUAVA TREE } \\
\hline 0.552 & 0.064 & 0.726 & 0.293 & 0.039 & 0.073 & Franco et al. (2007) ${ }^{7 /}$ \\
\hline 0.585 & 0.066 & 0.696 & 0.302 & 0.041 & 0.066 & Franco et al. (2007) $\stackrel{8}{-}$ \\
\hline 0.340 & 0.044 & 0.380 & 0.173 & 0.033 & 0.040 & Augostinho et al. (2008) \\
\hline \multicolumn{7}{|c|}{ SOURSOP TREE } \\
\hline 0.177 & 0.008 & 0.012 & 0.159 & 0.022 & $-\cdots$ & Barbosa et al. (2003) 10 \\
\hline
\end{tabular}

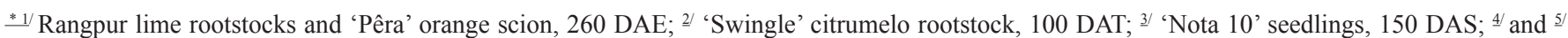
'Malásia' rootstocks, grafted 'B-10' and 'Golden Star', respectively, 308 DAT; $\underline{6}$ 'Malásia' rootstocks, 125 DAT; ${ }^{7}$ and ${ }^{8 /}$ 'Paluma' and 'Século XXI' seedlings, respectively, 120 DAT; ${ }^{9 /}$ 'Pedro Sato' seedlings, 120 DAT; 10/ 'Morada' seedlings, 195 days after transplant. 
Table 2. Amount of total dry matter mass (TDM) and micronutrients accumulated in rootstocks and seedlings of different species.

\begin{tabular}{|c|c|c|c|c|c|c|}
\hline TDM & B & $\mathbf{C u}$ & $\mathbf{F e}$ & Mn & $\mathbf{Z n}$ & Reference \\
\hline \multicolumn{7}{|c|}{ 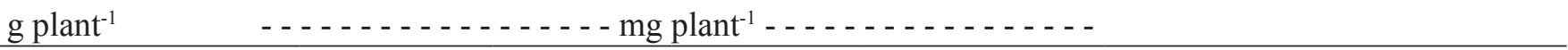 } \\
\hline \multicolumn{7}{|c|}{$\begin{array}{ll}\text { CITRUS } \\
\end{array}$} \\
\hline 31.66 & - & 0.256 & 4.644 & 2.003 & 0.104 & Rezende et al. (2010) ${ }^{1 /}$ \\
\hline 7.38 & 0.223 & 0.907 & 0.988 & 0.694 & 0.236 & Tecchio et al. (2006) 2 \\
\hline \multicolumn{7}{|c|}{ STAR FRUIT TREE } \\
\hline 45.65 & 1.753 & 0.616 & 28.071 & 5.850 & 2.271 & Freitas et al. (2011) ${ }^{\underline{3}}$ \\
\hline 57.11 & 1.981 & 1.593 & 11.878 & 3.622 & 1.404 & Rozane et al. (2011b) 4/ \\
\hline 58.76 & 1.885 & 1.431 & 12.544 & 3.680 & 1.349 & Rozane et al. (2011b) ${ }^{5 /}$ \\
\hline 23.12 & 0.722 & 0.096 & 2.936 & 2.165 & 0.780 & Rozane et al. (2013) 6 \\
\hline \multicolumn{7}{|c|}{ GUAVA TREE } \\
\hline 23.63 & 0.632 & 0.134 & 8.103 & 3.052 & 0.760 & Franco et al. (2008a) ${ }^{\frac{7}{}}$ \\
\hline 28.49 & 0.783 & 0.158 & 5.534 & 3.709 & 0.997 & Franco et al. (2008a) $\stackrel{8}{8}$ \\
\hline 19.51 & 0.743 & 0.118 & 5.114 & 2.151 & 0.566 & Augostinho et al. (2008) \\
\hline \multicolumn{7}{|c|}{ SOURSOP TREE } \\
\hline 12.12 & - - $^{-}$ & 0.068 & 1.31 & 0.23 & 0.51 & Barbosa et al. (2003) $10 /$ \\
\hline
\end{tabular}

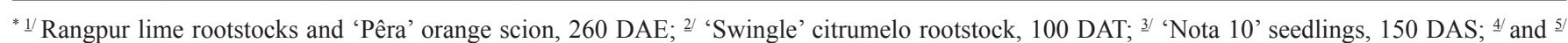
'Malásia' rootstocks, grafted 'B-10' and 'Golden Star', respectively, 308 DAT; ${ }^{6 /}$ 'Malásia' rootstocks, 125 DAT; ${ }^{7 /}$ and ${ }^{8 /}$ 'Paluma' and 'Século XXI' seedlings, respectively, 120 DAT; ${ }^{2 /}$ 'Pedro Sato' seedlings, 120 DAT; 10 / 'Morada' seedlings, 195 days after transplant.

Star fruit trees, just like other fruit tree species, show slow initial growth until 50 DAT. Dry matter mass accumulation in these plants is represented by a sigmoid curve. In seedlings grafted on 'Nota-10' cultivar, evaluated until 150 days after sprouting (DAS), plants presented half of their total dry matter in leaves, stem, roots and whole plant, in the interval between 82 and 118 days, indicating slow growth of the species (FREITAS et al., 2011). For 'Malásia' cultivar, $50 \%$ of dry matter mass accumulated by plants in different organs was reached between 97 and 106 DAT (ROZANE et al., 2013).

Nutrient accumulation in star fruit tree rootstocks and seedlings shows the same trend as dry matter mass accumulation in plants, and the period with the highest nutritional demand is between 90 and 150 DAT for 'Nota10' (FREITAS et al., 2011) and between 25 and 75 DAT for 'Malásia' rootstocks (ROZANE et al., 2013). For 'B-10' and 'Golden Star' cultivars, the interval of highest nutritional demand occurred between 208 and 233 DAT and between 233 and 283 DAT, respectively (ROZANE et al., 2011b).

Nutrient uptake rate and dry matter mass accumulation in guava tree seedlings vary according to cultivar. In general, dry matter mass growth and accumulation in the different organs of seedlings are slow until 45 days. Macronutrient accumulation in the seedlings of 'Paluma' cultivar increases quickly from the $75^{\text {th }}$ day. For the 'Século XXI' cultivar, this increase occurs at 45 DAT (FRANCO et al., 2007). In these two cultivars, half the dry matter mass accumulation takes place in the period from 75 to 94 and between 80 and 90 days, respectively; this is also the time gap during which plants concentrate macronutrients (FRANCO et al., 2007). Regarding micronutrients, the time necessary for plants to reach $50 \%$ accumulation was between 82 and 92 DAT and between 76 and 91 DAT, respectively, for 'Paluma' and 'Século XXI' cultivars, and dry matter mass accumulation in different organs followed the same trend (FRANCO et al., 2008a). In plants of 'Pedro Sato' cultivar, the period of most intense nutrient accumulation was between 60 and 90 DAT (AUGOSTINHO et al., 2008).

Seedling growth and dry matter mass accumulation in soursop trees presented small increment until 105 days of cultivation, a standard that was also observed for nutrient uptake rate and accumulation. In this period, plants accumulated $27 \%$ of the total dry matter mass and one third of nutrients. The remaining two thirds were accumulated from 105 to 190 days of cultivation (BARBOSA et al., 2003).

To supply the nutritional demands of rootstocks and seedlings, the amount to be applied via fertilization must take into account the amount accumulated by plants and the nutrient recovery rate, given that not every element provided as fertilizer is absorbed. It is necessary to be aware about the importance of nutrient balance, because the speed that nurserymen try to impose to the growth of rootstocks and seedlings often causes the dose of a certain nutrient to be excessive, which may compromise absorption of other nutrients and lead to nutritional imbalance.

Knowledge of nutritional demands of rootstocks and seedlings is fundamental to determining the amounts of nutrients to be offered to plants during the nursery phase. However, more studies are needed to determine 
these requirements in other species and complete the range of plants commonly produced in nurseries.

\section{Fertilizer recommendation for rootstocks} and seedlings - Rootstock and seedling production is usually carried out in protected environments, which demands nurserymen to be aware of some factors that may affect the normal growth of plants. According to Akpo et al. (2014), in addition to adequate irrigation, the factors that affect the growth of seedlings in nurseries are container size, substrate type and fertilizer supply.

Fertilization of rootstocks and seedlings aims to complement nutritional demands that are not fully met by the substrate and promote plant growth. Nevertheless, it is necessary to define adequate doses to maximize plant growth and make production economically feasible. It is important to stress that, despite the importance of fertilization for plant growth, the use of high doses of fertilizers causes losses to fruit tree rootstocks and seedlings (LIMA NETO et al., 2015), given that it may alter their morphology and influence their development in the field. In addition to determining the adequate dose, it is necessary to fractionate fertilization, especially regarding nitrogen and potassium, because nutrient leaching can occur as a consequence of constant irrigation and small dimension of recipients (plastic tubes) containing plants (PRADO et al., 2008; PRADO et al., 2009; ROZANE et al., 2009a). These losses may reach $8 \%, 12 \%$ and $26 \%$ for $\mathrm{N}, \mathrm{P}$ and $\mathrm{K}$, respectively, with nutrient management system, and $7 \%, 10 \%$ and $56 \%$ when slow-release fertilizers are used, as found by Boaventura et al. (2004), evaluating nutrient balance in citrus seedlings grown in commercial substrates.

Despite the known importance of nutrition for the production and quality of rootstocks and seedlings, literature presents many discrepancies regarding fertilizer management, dose definition, nutrient sources, application forms and installment. It is noteworthy that the doses of fertilizers for fruit tree rootstocks and seedlings, in general, are defined with little accuracy or empirically (LIMA NETO et al., 2015). Fertilization in nurseries is often carried out without adequate technical support, as a consequence of the absence of scientific information to help evaluating the nutritional status of plants in the nursery stage (SOUZA et al., 2015). In this context, there are greater concerns regarding micronutrients, given that there is a fine line between shortage and toxicity, especially in nurseries (LIMA NETO et al., 2015).

The importance of micronutrient fertilization in rootstocks and seedlings is notorious, because it affects the growth and nutritional status of plants; however, it is necessary to take into account that doses higher than recommended can cause toxicity and compromise the growth and quality of seedlings (SILVA-MATOS et al., 2016), which reinforces the importance of defining rational doses of fertilizers.

The amounts of nutrients offered to rootstocks and seedlings vary as a function of fertilizer management practices adopted in nurseries (GIRARDI et al., 2010). These authors evaluated fertilizer management practices recommended by fertilizer companies based on empirical experiences of nurserymen, and observed that, for the same nutrient, amounts provided for seedlings presented variations higher than $1,000 \%$ among some treatments.

Current fertilizer recommendation reports do not address fertilization of plants in nursery phase, which impairs the production of properly nourished rootstocks and seedlings. Some studies use fertilizer recommendation suggested by Malavolta (1980) for greenhouse experiments, which consists of $\mathrm{N}=300, \mathrm{P}=$ $200, \mathrm{~K}=150, \mathrm{Ca}=75, \mathrm{Mg}=15, \mathrm{~S}=50, \mathrm{~B}=0.5, \mathrm{Cu}=1.5$, $\mathrm{Mo}=0.1, \mathrm{Zn}=5.0$ and $\mathrm{Fe}=5.0\left(\mathrm{mg} \mathrm{dm}^{-3}\right)$. It is important to emphasize that this recommendation indicates the need to split $\mathrm{N}$ and $\mathrm{K}$ doses in two or three applications, with the first one occurring during planting and the others as topdressings during plant development. Nevertheless, this recommendation was designed for soil cultivation and extended to other environments without taking into account the specific demands of each species or variety.

Fertilization of rootstocks and seedlings is often underrated by research groups, and more studies are necessary to examine the characteristics of other economically important fruit trees. To guide the fertilization of rootstocks and seedlings and new studies, Table 3 presents nutrient doses associated with maximum growth for some species, as reported in several publications. In some papers, doses were expressed in different units (for instance, g/plant) and standardized to the same unit, taking into account the volume of containers in which plants were cultivated.

The supply of macronutrients to rootstocks and seedlings may also be carried out via nutrient solution. For citrus fruit trees, Bataglia et al. (2008) formulated nutrient solution considered balanced for substrate cultivation, containing $\left(\mathrm{mg} \mathrm{L}^{-1}\right) \mathrm{N}=200, \mathrm{P}=18, \mathrm{~K}=152, \mathrm{Ca}=140$, $\mathrm{Mg}=29$ and $\mathrm{S}=21$. 
Table 3. Macronutrient doses that promoted maximum growth in rootstocks and seedlings of different species, as reported by different studies.

\begin{tabular}{|c|c|c|c|}
\hline $\mathbf{N}$ & $\mathbf{P}$ & $\mathbf{K}$ & References \\
\hline \multicolumn{4}{|c|}{-- - - - - - - - mg dmº } \\
\hline \multicolumn{4}{|c|}{ CITRUS (rootstocks) } \\
\hline 920 & 100 & 790 & Rozane et al. (2007) $\frac{1 /}{2}$; Rozane et al. (2009a) $\stackrel{2}{2}$ \\
\hline 920 & 710 & 526 & Ruschel et al. (2004) 3 \\
\hline \multicolumn{4}{|c|}{ CITRUS (seedlings) } \\
\hline 459 & 184 & 876 & Prado et al. (2008) 4 \\
\hline 459 & 92 & 438 & Prado et al. (2009) $\underline{5}$ \\
\hline 2,592 & 753 & 2,100 & Bernardi et al. (2000) $\frac{6}{6}$ \\
\hline 1,836 & 368 & 876 & Arouca et al. (2011) $\underline{7}$ \\
\hline \multicolumn{4}{|c|}{ GUAVA TREE } \\
\hline 800 & 257 & 1,452 & Dias et al. (2012) $\stackrel{8}{\text {; }}$ Batista et al. (2011) ${ }^{9}$ \\
\hline \multicolumn{4}{|c|}{ PASSION FRUIT TREE } \\
\hline 150 & 160 & 300 & Almeida et al. (2006) ${ }^{10}$; Brasil e Nascimento (2010) 11 \\
\hline 340 & 267 & 300 & 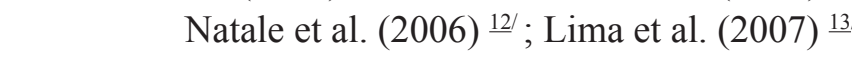 \\
\hline & 450 & 220 & Prado et al. (2005) 14/; Prado et al. (2004a) 15 \\
\hline \multicolumn{4}{|c|}{ PAPAYA TREE } \\
\hline 1,625 & 600 & - & Mendonça et al. (2009) 16/; Vichiato et al. (2009) 17 \\
\hline \multicolumn{4}{|c|}{ UMBU TREE } \\
\hline 286 & 281 & 208 & Neves et al. (2007a) $\frac{18}{2} ;(2007 b) \underline{19} ;(2008 a) \underline{20}$ \\
\hline
\end{tabular}

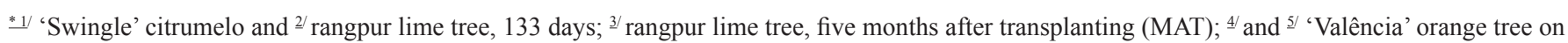
'Swingle' citrumelo tree and rangpur lime tree, respectively, 424 days after sowing; ${ }^{6 /}$ 'Valência' orange tree on rangpur lime tree, 10 MAT; ${ }^{7 /}$ 'Tahiti' lime tree grafted on 'Flying Dragon' tree, 215 days after grafting; $\stackrel{8 /}{-} \mathrm{N}, \mathrm{K}$ and ${ }^{9 /} \mathrm{P}$ in 'Paluma', 120 and 100 DAT, in substrate and soil, respectively; $\frac{10}{}$ $\mathrm{N}, \mathrm{K}$ and $\underline{11 /} \mathrm{P}$ in yellow passion fruit tree cultivated in soil, $84 \mathrm{DAE}$ and $50 \mathrm{DAT} ; \underline{12} \mathrm{~N}, \mathrm{~K}$ and $\stackrel{13 /}{\mathrm{P}}$ in seedlings cultivated in soil, $84 \mathrm{DAE}$ and 92 days after sowing; ${ }^{14} / \mathrm{P}$ and $15 / \mathrm{K}$ in seedlings cultivated in soil, 70 and 60 days after sowing, respectively; 16 ' 'Formosa' variety cultivated in commercial substrate, 150 days; $\underline{17 /}$ 'Improved Sunrise Solo 72/12' and 'Tainung 01' hybrid, 120 days after sowing; ${ }^{18 /} \mathrm{N}, \underline{19 /} \mathrm{P}$ and $\underline{20 /} \mathrm{K}$, seedlings cultivated in soil.

Information about micronutrient fertilization for fruit tree rootstocks and seedlings is even more uncommon in literature. Some investigations have reported doses that promoted maximum plant growth, but for few micronutrients and cultures. It has been advocated that fertilization is performed with $3.8 \mathrm{mg} \mathrm{dm}^{-3}$ of $\mathrm{Zn}$ for star fruit trees (LIMA NETO et al., 2015), $2 \mathrm{mg} \mathrm{dm}^{-3}$ of $\mathrm{Zn}$ for guava trees (NATALE et al., 2002), $5 \mathrm{mg} \mathrm{dm}^{-3}$ of $\mathrm{Zn}$ for yellow passion fruit trees (NATALE et al., 2004) and $0.5 \mathrm{mg} \mathrm{dm}^{-3}$ of B (PRADO et al., 2006). It is important to emphasize that most of these doses were determined for soil cultivation, and that substrate cultivation demands the definition of specific doses.

Some fertilizer recommendations for rootstocks and seedlings have been described in some publications. For citrus fruit trees, Bernardi et al. (2000) recommend the application of micronutrients through monthly spraying with the following doses $\left(\mathrm{mg} \mathrm{L}^{-1}\right)$ : $\mathrm{B}=0.2, \mathrm{Mn}=0.5$ and $\mathrm{Zn}=0.6$. Boaventura et al. (2004) suggest that nutrients are applied through nutrient solution via fertigation according to the following composition $\left(\mathrm{mg} \mathrm{L}^{-1}\right)$ : $\mathrm{B}=0.51, \mathrm{Cu}=0.13$, $\mathrm{Fe}=1.8, \mathrm{Mn}=0.54, \mathrm{Zn}=0.23$ and $\mathrm{Mo}=0.10$, in three weekly fractions and with volume of $250 \mathrm{~mL}$ of nutrient solution for each plant, totaling $750 \mathrm{~mL}$ per week. Mattos Junior et al. (2010) recommended nutrient application via irrigation water in the following concentrations $(\mathrm{mg}$ $\left.\mathrm{L}^{-1}\right): \mathrm{B}=0.55, \mathrm{Fe}=1.8, \mathrm{Mn}=0.54, \mathrm{Zn}=0.23$ and $\mathrm{Mo}=$ 0.10 . For yellow passion fruit trees, Fonseca et al. (2005) propose the following application $\left(\mathrm{mg} \mathrm{kg}^{-1}\right)$ : $\mathrm{B}=0.5, \mathrm{Cu}$ $=1.5, \mathrm{Mn}=3.0, \mathrm{Zn}=5.0$ and $\mathrm{Mo}=0.1$.

The adoption of commercial substrates instead of soil and other materials in the production of seedlings demands more fractions or a more frequent application of fertilizers, as a consequence of the susceptibility that these substrates have to leaching-driven nutrient loss (SERRANO et al., 2010). Alternatives such as fertigation and slow-release fertilizers have been used to produce fruit tree rootstocks and seedlings in an attempt to minimize these losses (COSTA et al., 2011; ALMEIDA et al., 2012).

The use of slow or controlled-release fertilizers has resulted in higher fertilization efficiency in nurseries, in comparison with fertigation and conventional fertilizers (GIRARDI et al., 2010; COSTA et al., 2011; ALMEIDA et al., 2012). However, it is necessary to carry out calibration studies to determine adequate doses for different cultivation conditions of rootstocks and seedlings of several species. It is important to ensure that the fertilizer supply is performed based on each species' growth curve, which implies fulfillment of plants' demands and loss reduction. 
Foliar diagnosis in fruit tree rootstocks and seedlings - Foliar diagnosis is the most reliable method to assess the nutritional status of plants (ARROBAS et al., 2014), and consists of evaluating soil fertility using plants as extractors. The higher reliability can be explained by the fact that soil is a heterogeneous medium, subject to several interactions that may compromise nutrient uptake by plants, even when fertility is high. Nevertheless, it is pertinent to stress that foliar analysis does not imply excluding soil analysis; rather, it could be used as complement, allowing adjusting fertilizer recommendation.

The diagnosis of the nutritional status of plants is carried out by comparing the content of nutrients obtained in the analyzed vegetal organ to reference values previously measured in calibration experiments, conducted in the field or greenhouses, where species can be grown under controlled nutritional and environmental conditions.

There have been few advances in the application of this technique in the production of fruit tree rootstocks and seedlings over the years. Literature lacks information on adequate nutritional standards, quantity and type of leaf to be sampled, and sampling period for most fruit tree species. This information is fundamental, because it allows setting fertilization characteristics whenever necessary, which helps producing high-quality seedlings.

When evaluating the nutritional condition of each species, it is indispensable that factors such as leaf type and sampling period are similar to those used to obtain reference values. For rootstocks and seedlings of most cultures, there is no standardization for leaf type, let alone for proper sampling period. This causes researchers and producers to resort to empiricism, which leads them to apply standards determined for plants in production phase, that is, adult plants, resulting in severe interpretation problems.

Leaf nutrient content varies according to species (GALVEZ-SOLA et al., 2015), cultivar, sampling period (CARVALHO et al., 2011; AMIRI et al., 2014; ARROBAS et al., 2014), leaf age, analyzed organ (ARROBAS et al., 2014) and rootstock (AMIRI et al., 2014; HROTKÓ et al., 2014; ZAMBROSI et al., 2013), among other factors. As a consequence of these variations, the ideal nutrient content must be specified for each plant species; the plant part also has to be indicated and, in some cases, the growth phase to which values relate should also be pointed out (MAARSCHALKERWEERD; HUSTED, 2015).

Leaf sampling to evaluate the nutritional status of plants is the first step in the diagnosis process, and one of the most important, because if it does not follow the correct procedures, the other stages will be compromised, and the diagnosis will not be reliable. For 'Paluma' and 'Século XXI' guava tree seedlings, Rozane et al. (2009b) recommended to collect the third pair of leaves from the apex to the basis of the branch. This indication was followed by Souza et al. (2015) to determine the leaf content for 'Paluma' seedlings.

For citrus rootstocks and seedlings, respectively, Bataglia et al. (2008) recommended the collection of thoroughly expanded ripe leaves located at the medium third of rootstock and seedlings; the recommended amounts are three per plant and twenty plants per plot. For sweet passion fruit trees (Passiflora alata Curtis), Freitas et al. (2008) suggested the collection of the fourth thoroughly expanded leaf and ten leaves per plot.

In the final diagnosis step, interpretation of leaf contents is carried out through several methods (ROZANE et al., 2016). For some cultures, such as passion fruit and umbu trees (Spondias tuberosa Arr. Cam.), critical leaf level and nutrient sufficiency range were applied to measure adequate nutrient contents. For guava and citrus trees, the Diagnosis and Recommendation Integrated System (DRIS) was used (Table 4).

Table 4 exhibits adequate macronutrient contents for rootstocks and seedlings of some fruit tree species. It is pertinent to stress that for yellow passion fruit trees, the critical level was determined in the entire plant shoot, and not only in the foliar portion (NATALE et al., 2006; PRADO et al., 2004a; PRADO et al., 2004b; PRADO et al., 2005; PRADO et al., 2006). For cultures with lack of such information, Table 4 shows contents obtained in studies reporting hydroponic growing, which may be used as a guide by seedling producers and reference for the development of new investigations. It is important to point out that different cultivation conditions may result in different outcomes.

For papaya fruit trees, nutrient contents (Tables 4 and 5) in plant shoot were calculated to promote from $90 \%$ to $100 \%$ of maximum seedling growth, based on regression equations presented by Serrano et al. (2010). In cases in which this calculation was not possible, the average contents obtained in the mentioned study were shown.

Macronutrient contents differ among species and cultivars and within the same species (Table 4). This must be taken into account during the interpretation of results of plant tissue analysis in order to avoid mistakes, and wrong diagnoses are not carried out. In general, for some macronutrients, such as $\mathrm{N}, \mathrm{K}$ and $\mathrm{Ca}$, this range is wider, as a consequence of the greater requirement of these elements by plants. For $\mathrm{P}, \mathrm{Mg}$ and $\mathrm{S}$, the range is narrower, which may indicate lower demand of these nutrients by plants. 
Table 4. Foliar content and macronutrient content range for rootstocks and seedlings of different species, as reported by different studies.

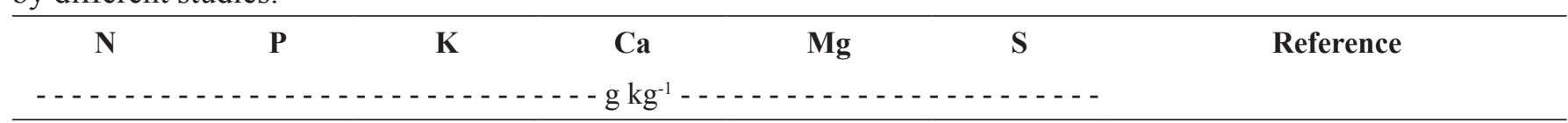

\section{CITRUS (rootstocks)}

$\begin{array}{lllllll}34.0-36.9 & 2.4-2.9 & 19.1-22.1 & 22.5-27.3 & 3.2-3.9 & 3.0-3.7 & \text { Bataglia et al. (2008) }{ }^{1 /} \\ 34.6-37.3 & 2.3-2.6 & 18.2-23.4 & 21.1-24.5 & 3.4-4.0 & 2.9-3.2 & \text { Bataglia et al. (2008) })^{2 /} \\ 28.1-32.4 & 1.9-2.3 & 12.8-16.5 & 25.6-31.7 & 3.3-3.6 & 3.2-4.0 & \text { Bataglia et al. (2008) }{ }^{3 /} \\ 37.8-41.2 & 2.3-2.8 & 20.0-22.8 & 24.2-29.9 & 3.5-4.2 & 3.9-4.3 & \text { Bataglia et al. (2008) })^{4 /}\end{array}$

\section{CITRUS (established seedlings)}

\begin{tabular}{|c|c|c|c|c|c|c|}
\hline $32.0-35.7$ & $2.0-2.4$ & $21.0-24.2$ & $20.8-26.7$ & $2.2-2.5$ & $2.9-3.3$ & Bataglia et al. (2008) $)^{\frac{5}{}}$ \\
\hline $36.0-39.2$ & $2.1-2.4$ & $22.4-24.9$ & $23.5-26.5$ & $2.5-2.9$ & $3.3-3.7$ & Bataglia et al. (2008) \\
\hline \multicolumn{7}{|c|}{ STAR FRUIT TREE } \\
\hline $30.0-33.2$ & $2.6-3.1$ & $24.7-33.7$ & $12.5-15.1$ & $4.2-5.9$ & $3.1-4.0$ & Rozane et al. (2011a) ${ }^{7 /}$ \\
\hline \multicolumn{7}{|c|}{ GUAVA TREE } \\
\hline $24.0-28.0$ & $2.4-3.1$ & $21.0-29.0$ & $6.0-8.0$ & $1.9-2.9$ & $1.9-2.3$ & Souza et al. $(2015)^{\stackrel{8}{8}}$ \\
\hline $30.8-32.8$ & $3.2-3.4$ & $27.9-33.8$ & 11.1 & $1.9-2.5$ & $3.2-3.5$ & Franco and Prado (2006) ${ }^{9 /}$ \\
\hline $30.0-33.8$ & $3.3-4.1$ & $23.2-30.9$ & 10.4 & $1.9-2.7$ & $3.2-3.9$ & Franco and Prado (2006) $\frac{10}{0}$ \\
\hline \multicolumn{7}{|c|}{ SOURSOP TREE } \\
\hline 33.4 & 1.3 & 51.4 & 18.8 & 2.8 & - & Barbosa et al. (2003) $\underline{11}$ \\
\hline 30 & 1.3 & 22.5 & 5.2 & 1.3 & 1.51 & Silva and Farnezi (2009) $\underline{12}$ \\
\hline
\end{tabular}

\section{PASSION FRUIT TREE}

\begin{tabular}{|c|c|c|c|c|c|c|}
\hline $33.0-44.0$ & 4.50 & $32.5-39.9$ & 12.8 & 4.0 & - & $\begin{array}{l}\text { Prado et al. }(2005)^{\frac{14}{4} ;} ;(2004 \mathrm{a} \\
(2004 \mathrm{~b}) \frac{16 /}{16}\end{array}$ \\
\hline 43.4 & 2.47 & 27.4 & 15.6 & 3.8 & 5.28 & Freitas et al. 2008 \\
\hline \multicolumn{7}{|c|}{ PAPAYA TREE } \\
\hline $47.5-53.7$ & 3.1 & $44.4-52.7$ & 15.0 & $11.1-12.3$ & 5.5 & Serrano et al. (2010) 18 \\
\hline $36.5-43.2$ & 2.6 & $35.2-39.4$ & 13.0 & $9.6-9.8$ & 5.3 & Serrano et al. (2010) \\
\hline $40.9-44.3$ & 2.6 & $39.9-44.5$ & $11.9-12.0$ & $9.9-11.6$ & 4.7 & Serrano et al. (2010) 20/ \\
\hline $39.4-44.9$ & $4.4-5.5$ & $45.5-50.1$ & 15.0 & $10.5-11.5$ & 5.0 & Serrano et al. (2010) 21/ \\
\hline $42.4-46.1$ & 2.5 & $41.4-47.7$ & 15.0 & $11.0-11.4$ & $5.1-5.5$ & Serrano et al. (2010) 222 \\
\hline
\end{tabular}

UMBU TREE

$25.7-29.5 \quad 1.5-1.9 \quad 3.4-6.0 \quad 18.3-21.5 \quad 2.8-3.3$

Neves et al. (2007a) ${ }^{23} ;$; (2007b) ${ }^{24}$; (2008a) $\frac{25}{5}$; (2008b) $\underline{26}$

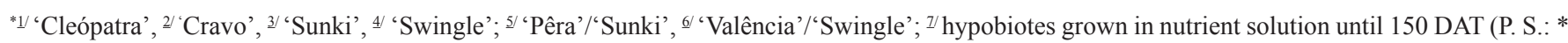
ranges based on variation of contents as a function of the different solutions used); ${ }^{8 /}$ 'Paluma' cultivar grown in substrate, 120 days; ${ }^{9 /}$ 'Paluma' and $\underline{10}$ ' 'Século XXI' cultivars grown in nutrient solution, 90 days after treatments; ${ }^{11 /}$ and $\underline{12 /}$ 'Morada' cultivar, grown in soil, 150 and 120 days; ${ }^{13 /} \mathrm{N}, \underline{14} \mathrm{P}, \underline{15 /} \mathrm{K}, \stackrel{16 /}{\mathrm{Ca}}$ and $\mathrm{Mg}$, yellow passion fruit tree, grown in soil, 84, 70, 60 and 80 days (P. S.: for $\mathrm{N}$ and $\mathrm{K}$, the values referring to $90 \%$

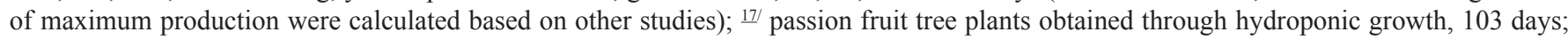

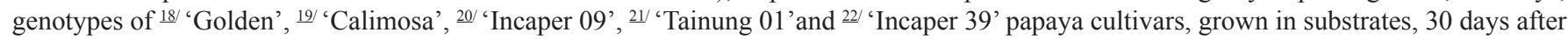
sowing; ${ }^{23 /} \mathrm{N}, \underline{24 /} \mathrm{P}, \underline{25 /} \mathrm{K}, \stackrel{26 /}{\mathrm{Ca}}$ and $\mathrm{Mg}$, seedlings grown in soil. 
Lack of information about adequate contents in fruit tree rootstocks and seedlings is even greater for micronutrients. Although they are necessary in smaller amounts, they are essential and play a crucial role in plant nutrition, and special attention must be given when determining the adequate range of leaf nutrient contents. This caution is due to lower demand in quantitative terms (Table 5), which makes the interval between deficiency and toxicity narrow in plants (MALAVOLTA et al., 1997).

Table 5. Foliar content and micronutrient content range for rootstocks and seedlings of different species, as reported by different studies.

\begin{tabular}{|c|c|c|c|c|c|}
\hline $\mathbf{B}$ & $\mathbf{C u}$ & $\mathbf{F e}$ & Mn & $\mathbf{Z n}$ & Reference \\
\hline \multicolumn{6}{|c|}{ CITRUS (rootstocks) } \\
\hline $105-143$ & $36.0-38.9$ & $110-140$ & $135-190$ & $26.7-33.8$ & Bataglia et al. (2008) $\frac{1}{1}$ \\
\hline $65-120$ & $4.6-7.5$ & $113-211$ & $53-71$ & $20.4-51.3$ & Bataglia et al. (2008) $\stackrel{2}{2}$ \\
\hline $72-140$ & $15.7-30.9$ & $102-184$ & $60-93$ & $27.3-41.8$ & Bataglia et al. $(2008)^{\frac{3}{3}}$ \\
\hline $116-177$ & $20.9-31.3$ & $146-221$ & $153-243$ & $24.7-35.7$ & Bataglia et al. (2008) \\
\hline \multicolumn{6}{|c|}{ CITRUS (established seedlings) } \\
\hline $101-130$ & $9.8-12.0$ & $188-261$ & $90-146$ & $40.8-61.4$ & Bataglia et al. (2008) $\frac{5}{6}$ \\
\hline $91-124$ & $14.9-18.4$ & $167-238$ & $74-125$ & $41.1-52.7$ & Bataglia et al. (2008) 6 \\
\hline \multicolumn{6}{|c|}{ STAR FRUIT TREE } \\
\hline $69-81$ & $3-4$ & $116-144$ & $266-433$ & $35-46$ & Rozane et al. (2011a) ㄱ \\
\hline \multicolumn{6}{|c|}{ GUAVA TREE } \\
\hline $35-48$ & $4-15$ & $68-93$ & $180-245$ & $31-60$ & Souza et al. (2015) $\stackrel{8}{8}$ \\
\hline 31 & 2 & 106 & 116 & 21 & Franco and Prado (2008) 9 \\
\hline 29 & 3 & 102 & 109 & 24 & Franco and Prado (2008) 10 \\
\hline \multicolumn{6}{|c|}{ SOURSOP TREE } \\
\hline- & 5.4 & 120.7 & 38.0 & 33.7 & Barbosa et al. (2003) \\
\hline 58.2 & $\therefore$ & - & - & 22.4 & Silva and Farnezi (2009) 12 \\
\hline \multicolumn{6}{|c|}{ PASSION FRUIT TREE } \\
\hline 22.0 & - & - & - & - & Prado et al. (2006) $\underline{13}$ \\
\hline 64.0 & 2.25 & 116 & 80 & 22 & Freitas et al. (2008) 14 \\
\hline \multicolumn{6}{|c|}{ PAPAYA TREE } \\
\hline 111.9 & 15.0 & 187 & $79.4-94.9$ & 37.7 & Serrano et al. (2010) $\frac{15}{f}$ \\
\hline 88.3 & 12.8 & 208 & $61.8-72.8$ & 35.5 & Serrano et al. (2010) $\frac{16}{16}$ \\
\hline 97.7 & 12.1 & 182 & $60.8-67.6$ & 31.8 & Serrano et al. (2010) $\frac{17}{17}$ \\
\hline 108.1 & 11.1 & 146 & 66.3 & 67.5 & Serrano et al. (2010) $\underline{18}$ \\
\hline 113.3 & 11.2 & 145 & $61.2-70.1$ & 47.1 & Serrano et al. (2010) 19 \\
\hline
\end{tabular}

/ 'Cleópatra', 2/ 'Cravo', 3/ 'Sunki', 4/ 'Swingle'; 5/ 'Pêra'/'Sunki', 6/ 'Valência'/'Swingle' (according to the authors, Cu and Zn contents were altered as a consequence of spraying, which hindered a reliable interpretation of results for these nutrients); ${ }^{7 /}$ hypobiotes grown in nutrient

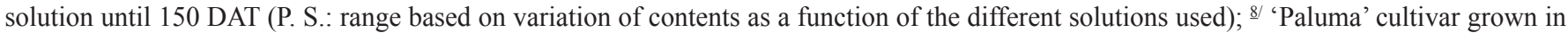
substrate, 120 days; ${ }^{2 /}$ 'Paluma' and $\underline{10}$ ' 'Século XXI' cultivars grown in nutrient solution, 90 days after treatments; $\underline{11 /}$ and $\underline{12}$ ' 'Morada' cultivar,

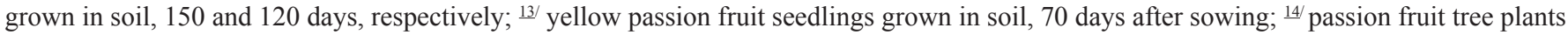

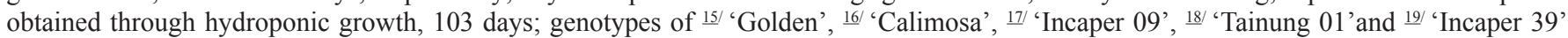
papaya cultivars, grown in substrates, 30 days after sowing. 
For micronutrients, nutrient contents in leaf tissues are often so low that they make it difficult to establish critical levels or sufficiency ranges. Sample contamination and errors during digestion and analysis may lead to false conclusions (MAARSCHALKERWEERD; HUSTED, 2015).

\section{Cultivation setting for growth of fruit tree} seedlings - To meet technical and legal prerequisites and follow the evolution of pathogens that contaminate fruit trees, modifications of traditional seedling production processes have been constantly updated and reviewed by plant technology agencies.

Law $\mathrm{n}^{\circ}$ 10,711, issued on August 52003 and currently in force, decides on the Brazilian Center for Seeds (Sistema Nacional de Sementes e Mudas) and provides other measures to guarantee the identity and quality of vegetal multiplication and breeding material, that is, seeds and seedlings produced, commercialized and used in Brazilian territory. It is important to emphasize Decree 5153/2004, which regulates law and Normative Instructions $n^{\circ} 9 / 2005, n^{\circ} 24 / 2005, n^{\circ} 50 / 2006, n^{\circ} 42 / 2009$ and $n^{\circ} 02 / 2010$, determining rules for production, commercialization and use of seeds and seedlings, in addition to other actions.

According to Article 8, people and companies that develop production, processing, packing, storage, analysis, commerce, import and export of seeds and seedlings have to report to the Brazilian Registry of Seeds and Seedlings (Renasem, its acronym in Portuguese). Registration is responsibility of the Brazilian Ministry of Agriculture, Livestock and Supply (MAPA, its acronym in Portuguese), which is also empowered to perform the Brazilian Registry of Cultivars (RNC, its acronym in Portuguese) and the Brazilian Entity of Registered Cultivars (CNCR, its acronym in Portuguese), a registration form for maintainers that provide basic material, ensuring the characteristics of the cultivar declared according to its registration at RNC. As a consequence of this legislation, seedling producers are allowed to use materials registered at RNC only for plant propagation and commercialization, and have their activities supervised by MAPA. Additionally to the national legislation, each Brazilian state has specific laws on the topic. São Paulo, for instance, requires the presence of a technical manager, who must be accredited by the ministry.

Seedling production is also cultivar specific. Citrus and coffee cultures are ruled by a distinct administrative rule (Portaria CDA - 5/2005 and 4/2011, respectively). An important legacy of these administrative rules refers to production of seedlings in substrates. The use of substrates instead of soil stands out among the several items associated with the production of healthy and high-quality seedlings, given that soil may favor dissemination of pests, diseases and weeds. Due to the importance of this aspect and the concern it raises, in the 1980s, the $S A A-80 / 1984$ resolution was enacted, which prohibited the dispatch of soil and seedlings of São Miguel Arcanjo, Guareí, Pardinho, Itatinga and Capão Bonito municipalities, given that they hosted ground pearl (Eurhizococcus brasiliensis). Since then, several administrative rules were enacted according to potential cultures, pests or diseases, in addition to rootstock or seedling production site.

At national level, MAPA, by means of Normative Instruction $n^{\circ} 24 / 2005$, does not restrict the use of soil or soil mixture, but item 5.2, subparagraph I determines that producers must take responsibility for production, quality production and identity of seedlings in every production step.

When seedlings or rootstocks are grown in substrates, which usually cannot provide plants with adequate and balanced nutrition, it is necessary to apply amendments to correct soil acidity and fertilizers. Although several administrative rules and normative instructions have been issued by competent bodies, almost all concerns relate to pathogens. These legal instruments do not contain guidelines on the chemical quality of substrates that will be used to produce rootstocks and seedlings.

Considering that the adoption of substrates aims to prevent dissemination of pests, diseases and weeds, most materials used for this purpose are inert, that is, they do not provide plants with the necessary amounts of nutrients. Since the use of inert substrates is relatively new in Brazil, little information is available about the handling of these recipients directed to make them more suitable for adequate plant grow. There is high research demand on this subject, given that each vegetal species has specific nutritional requirement. In addition, different substrates present distinct chemical compositions. Thus, the only way to fill this knowledge gap is through experimentation.

Some general measures should be taken in the period of initial seedling development, due to sensitivity to $\mathrm{pH}$ and salinity problems caused by fertilizers. Consequently, nutrient dose fractioning and adequate choice of nutrient source are fundamental for nurserymen to achieve success in their activities. 


\section{References}

AKPO, E.; STOMPH, T.J.; KOSSOU, D.K.; STRUIK, P.C. Growth dynamics of tree nursery seedlings: The case of oil palm. Scientia Horticulturae, Amsterdam, v.175, p.251-257, 2014.

ALMEIDA, E.V.; NATALE, W.; PRADO, R.M.; BARBOSA, J.C. Adubação nitrogenada e potássica no desenvolvimento de mudas de maracujazeiro. Ciência Rural, Santa Maria, v.36, n.4, p.1138-1142, 2006.

ALMEIDA, L.V.B.; MARINHO, C.S.; MUNIZ, R.A.; CARVALHO, A.J.C. Disponibilidade de nutrientes e crescimento de porta-enxertos de citros fertilizados com fertilizantes convencionais e de liberação lenta. Revista Brasileira de Fruticultura, Jaboticabal, v.34, n.1, p.289296, 2012.

AMIRI, M.E.; FALLAHI, E.; SAFI-SONGHORABAD, $M$. Influence of rootstock on mineral uptake and scion growth of 'Golden Delicious' and 'Royal Gala' apples. Journal of Plant Nutrition, New York, v.37, n.1, p.1629, 2014.

AROUCA, M.B.; PENNA, L.D.; PRADO, R.M.; ROZANE, D.E. Nitrogênio, fósforo e potássio na produção de massa seca e no acúmulo de nutrientes em mudas de limeira ácida 'tahiti'. Revista Brasileira de Ciências Agrárias, Recife, v.6, n.4, p.642-649, 2011.

ARROBAS, M.; FERREIRA, I.Q.; FREITAS, S.; VERDIAL, J.; RODRIGUES, M.Â. Guidelines for fertilizer use in vineyards based on nutrient content of grapevine parts. Scientia Horticulturae, Amsterdam, v.172, p.191-198, 2014.

AUGUSTINHO, L.M.D.; PRADO, R.M.; ROZANE, D.E.; FREITAS, N. Acúmulo de massa seca e marcha de absorção de nutrientes em mudas de goiabeira 'Pedro Sato. Bragantia, Campinas, v.67, n.3, p.577-585, 2008.

BARBOSA, Z.; SOARES, I.; CRISÓSTOMO, L. A. Crescimento e absorção de nutrientes por mudas de gravioleira. Revista Brasileira de Fruticultura, Jaboticabal, v.25, n.3, p.519-522, 2003.

BATAGLIA, O.C.; FURLANI, P.R.; FERRAREZI, R.S.; MEDINA, C.L. Padrão nutricional de mudas de citros. Araraquara: Vivecitrus/Conplant, 2008. 40 p.
BATAGLIA, O.C.; QUAGGIO, J.; ABREU, M.F.; BOAVENTURA, P.S.R. Nutrient uptake and leaching on citrus nursery production in substrate with two fertilizer management programs. Acta Horticulturae, The Hague, v.697, p.281-284, 2005.

BATISTA, M.A.V.; PRADO, R.M.; LEITE, G.A. Resposta de mudas de goiabeira a aplicação de fósforo. Bioscience Journal, Uberlândia, v.27, n.4, p.635-641, 2011.

BERNARDI,A.C.C.; CARMELLO, Q.A.C.; CARVALHO, S.A. Macronutrientes em mudas de citros cultivadas em vasos em resposta à adubação NPK. Scientia Agricola, Piracicaba, v.57, n.4, p.761-767, 2000.

BOAVENTURA, P.R.R; QUAGGIO, J.A.; ABREU, M.F.; BATAGLIA, O.C. Balanço de nutrientes na produção de mudas cítricas cultivadas em substrato. Revista Brasileira de Fruticultura, Jaboticabal, v.26, n.2, p.300-305, 2004.

BRASIL, E.C.; NASCIMENTO, E.V.S. Influência de calcário e fósforo no desenvolvimento e produção de variedades de maracujazeiro-amarelo. Revista Brasileira de Fruticultura, Jaboticabal, v.32, n.3, p.892-902, 2010.

CAO, X.; CHEN, C.; ZHANG, D.; SHU, B.; XIAO, J.; XIA, R. Influence of nutrient deficiency on root architecture and root hair morphology of trifoliate orange (Poncirus trifoliata L. Raf.) seedlings under sand culture. Scientia Horticulturae, Amsterdam, v.162, p.100-105, 2013.

CARVALHO,A.J.C.; FONTES, P.S.F.; FREITAS, M.S.M.; MONNERAT, P.H.; FONTES, A.G. Yellow passion fruit plant nutritional diagnosis at different phenological stages by the Diagnosis and Recommendation Integrated System Method. Journal of Plant Nutrition, New York, v.34, n.4, p.614-626, 2011.

COSTA, A.C.; DECARLOS NETO, A.; RAMOS, J.D.; BORGES, D.I. Alternativas para adubação de portaenxertos de abacateiro 'Quintal' e seu efeito no pegamento de enxertia. Revista Brasileira de Fruticultura, Jaboticabal, v.33, n.4, p.1283-1293, 2011.

DIAS, M.J.T.; SOUZA, H.A.; NATALE, W.; MODESTO, V.C.; ROZANE, D.E. Adubação com nitrogênio e potássio em mudas de goiabeira em viveiro comercial. Semina: Ciências Agrárias, Londrina, v.33, supl.1, p.2837-2848, 2012. 
FAOSTAT - Food and Agriculture Organization of the United Nations. Production-crops. Disponível em: $\leq \mathrm{http}$ //faostat3.fao.org/home/E $>$ Acesso em: 10 maio 2016.

FONSECA, E.B.A.; CARVALHO, J.G.; PASQUAL, M.; CORREAA, J.B.D. Concentração de micronutrientes em mudas de maracujazeiro-doce propagado por sementes em função da calagem. Ciência e Agrotecnologia, Lavras, v.29, n.1, p.43-51, 2005.

FRANCO, C.F.; PRADO, R.M. Nutrição de micronutrientes em mudas de goiabeira em resposta ao uso de soluções nutritivas. Acta Scientiarum. Agronomy, Maringá, v.30, n.3, p.403-408, 2008.

FRANCO, C.F.; PRADO, R.M. Uso de soluções nutritivas no desenvolvimento e no estado nutricional de mudas de goiabeira: macronutrientes. Acta Scientiarum. Agronomy, Maringá, v.28, n.2, p.199-205, 2006.

FRANCO, C.F.; PRADO, R.M.; BRAGHIROLLI, L.F.; ROZANE, D.E. Curva de crescimento e marcha de absorção de macronutrientes em mudas de goiabeira. Revista Brasileira de Ciência do Solo, Viçosa, MG, v.31, n.6, p.1429-1437, 2007.

FRANCO, C.F.; PRADO, R.M.; BRAGHIROLLI, L.F.; ROZANE, D.E. Marcha de absorção dos micronutrientes para mudas de goiabeiras cultivares Paluma e Século XXI. Bragantia, Campinas, v.67, n.1, p.83-90, 2008a.

FREITAS, M.S.M.; MONNERAT, P.H.; VIEIRA, I.J.C. Mineral deficiency in Passiflora alata Curtis: Vitexin bioproduction. Journal of Plant Nutrition, New York, v.31, n.10, 1844-1854, 2008.

FREITAS, N.; PRADO, R.M.; ROZANE, D.E.; TORRES, M.H.; AROUCA, M.B. Marcha de absorção de nutrientes e crescimento de mudas de caramboleira enxertada com a cultivar nota-10. Semina: Ciências Agrárias, Londrina, v.32, n.4, p.1231-1242, 2011.

GALVEZ-SOLA, L.; GARCÍA-SÁNCHEZ, F.; PÉREZPÉREZ, J.G.; GIMENO, V.; NAVARRO, J.M.; MORAL, R.; MARTÍNEZ-NICOLÁS, J.J.; NIEVES, M. Rapid estimation of nutritional elements on citrus leaves by near infrared reflectance spectroscopy. Frontiers in Plant Science, Lausanne, v.6, n.571, p.1-8, 2015.

GIRARDI, E.A.; MOURÃO FILHO, F.A.A.; ALVES, A.S.R. Mudas de laranjeira 'Valência' sobre dois portaenxertos e sob diferentes manejos de adubação. Revista Brasileira de Fruticultura, Jaboticabal, v.32, n.3, p.855864, 2010.
HROTKÓ, K.; MAGYAR, L.; BORSOS, G.; GYEVIKI, $M$. Rootstock effect on nutrient concentration of sweet cherry leaves. Journal of Plant Nutrition, New York, v.37, n.9, p.1395-1409, 2014.

LIMA NETO, A.J.; NATALE, W.; MODESTO, V.C. Resposta de porta-enxertos de caramboleira à adubação com zinco. Revista Brasileira de Fruticultura, Jaboticabal, v.37, n.4, p.1074-1082, 2015.

LIMA, R.A.F.; MENDONÇA, V.; TOSTA, M.S.; REIS, L.L.; BISCARO, G.A.; CHAGAS, E.A. Fósforo e zinco no crescimento de mudas de maracujazeiro-amarelo. Pesquisa Agropecuária Tropical, Goiânia, v.37, n.4, p.251-256, 2007.

MAARSCHALKERWEERD, V.; HUSTED, S. Recent developments in fast spectroscopy for plant mineral analysis. Frontiers in Plant Science, Lausanne, v.6, n.169, p.1-14, 2015.

MALAVOLTA, E. Elementos da nutrição mineral de plantas. São Paulo: Ceres, 1980. 251 p.

MALAVOLTA, E.; VITTI, G.C.; OLIVEIRA, S.A. Avaliação do estado nutricional das plantas: princípios e aplicações. 2. ed. Piracicaba: Potafós, 1997. 319 p.

MATTOS JUNIOR, D.; RAMOS, U.M.; QUAGGIO, J.A.; FURLANI, P.R. Nitrogênio e cobre na produção de mudas de citros em diferentes porta-enxertos. Bragantia, Campinas, v.69, n.1, p.135-147, 2010.

MEI, L.; SHENG, O.; PENG, S.A.; ZHOU, G.F.; WEI, Q.J.; LI, Q.H. Growth, root morphology and boron uptake by citrus rootstock seedlings differing in boron-deficiency responses. Scientia Horticulturae, Amsterdam, v.129, n.3, p.426-432, 2011.

MENDONÇA, V.; RAMOS, J.D.; ABREU, N.A.A.; TEIXEIRA, G.A.; SOUZA, H.A.; GURGEL, R.L.S.; ORBES, M.Y. Adubação nitrogenada em cobertura e substratos na produção de mudas de mamoeiro 'Formosa'. Ciência e Agrotecnologia, Lavras, v.33, n.3, p.668-675, 2009.

MINAMI, K.; TESSARIOLI NETO, J.; PENTEADO, S.R.; ESCARPARI FILHO, J.A. Produção de mudas hortícolas de alta qualidade. Piracicaba: ESALQ/ SEBRAE, 1994. $155 \mathrm{p}$.

NATALE, W.; PRADO, R.M.; ALMEIDA, E.V.; BARBOSA, J.C. Adubação nitrogenada e potássica no estado nutricional de mudas de maracujazeiro-amarelo. Acta Scientiarum. Agronomy, Maringá, v.28, n.2, p.187192, 2006. 
NATALE, W.; PRADO, R.M.; CORRÊA, M.C.M.; SILVA, M.A.C.; PEREIRA, L. Resposta de mudas de goiabeira à aplicação de zinco. Revista Brasileira de Fruticultura, Jaboticabal, v.24, n.3, p.770-773, 2002.

NATALE, W.; PRADO, R.M.; LEAL, R.M.; FRANCO, C.F. Efeitos da aplicação de zinco no desenvolvimento, no estado nutricional e na produção de matéria seca de mudas de maracujazeiro. Revista Brasileira de Fruticultura, Jaboticabal, v.26, n.2, p.310-314, 2004.

NEVES, O.S.C.; CARVALHO, J.G.; FERREIRA, E.V.O.; PEREIRA, N.V.; NEVES, V.B.F. Efeito da adubação nitrogenada sobre o crescimento e acúmulo de nutrientes em mudas de umbuzeiro. Revista Brasileira de Ciências Agrárias, Recife, v.2, n.3, p.200-207, 2007a.

NEVES, O.S.C.; CARVALHO, J.G.; OLIVEIRA, E.V.; ASSIS, R.P. Nutrição mineral, crescimento e níveis críticos foliares de cálcio e magnésio em mudas de umbuzeiro, em função da calagem. Revista Ceres, Viçosa, MG, v.55, n.6, p.575-583, 2008 b.

NEVES, O.S.C.; CARVALHO, J.G.; OLIVEIRA, E.V.; NEVES, V.B.F. Crescimento, nutrição mineral e nível crítico foliar de $\mathrm{P}$ em mudas de umbuzeiro, em função da adubação fosfatada. Revista Brasileira de Fruticultura, Jaboticabal, v.30, n.3, p.801-805, 2008a.

NEVES, O.S.C.; CARVALHO, J.G.; OLIVEIRA, E.V.; PEREIRA, N.V. Crescimento, nutrição mineral e nível crítico foliar de K em mudas de umbuzeiro, em função da adubação potássica. Ciência e Agrotecnologia, Lavras, v.31, n.3, p.636-642, 2007 b.

PERIN, J.R.; CARVALHO, S.A.; MATTOS JUNIOR, D.; CANTARELLA, H. Efeitos de substratos e doses de fertilizante de liberação lenta no teor de clorofila e desenvolvimento vegetativo do limoeiro 'Cravo' em tubetes. Laranja, Cordeirópolis, v.20, n.2, p.463-476, 1999.

PRADO, R.M.; NATALE, W.; CORRÊA, M.C.M.; B.L.F. Efeitos da aplicação de calcário no desenvolvimento, no estado nutricional e na produção de matéria seca de mudas de maracujazeiro. Revista Brasileira de Fruticultura, Jaboticabal, v.26, n.1, p.145-149, 2004b.

PRADO, R.M.; NATALE, W.; CORRÊA, M.C.M.; BRAGHIROLLI, L.F. Aplicação de potássio no estado nutricional e na produção de matéria seca de mudas de maracujazeiro-amarelo. Revista Brasileira de Fruticultura, Jaboticabal, v.26, n.2, p.295-299, 2004a.
PRADO, R.M.; NATALE, W.; ROZANE, D.E. Níveis críticos de boro no solo e na planta para cultivo de mudas de maracujazeiro-amarelo. Revista Brasileira de Fruticultura, Jaboticabal, v.28, n.2, p.305-309, 2006.

PRADO, R.M.; ROZANE, D.E.; CAMAROTTI, G.S.; CORREIA, M.A.R.; NATALE, W.; BARBOSA, J.C.; BEUTLER, A.N. Nitrogênio, fósforo e potássio na nutrição e na produção de mudas de laranjeira 'Valência', enxertada sobre citrumeleiro 'Swingle'. Revista Brasileira de Fruticultura, Jaboticabal, v.30, n.3, p.812-817, 2008.

PRADO, R.M.; ROZANE, D.E.; CAMAROTTI, G.S.; CORREIA, M.A.R.; NATALE, W.; BARBOSA, J.C. Nitrogênio, fósforo e potássio na nutrição e no crescimento de mudas de laranjeira valência, enxertadas sobre limoeiro cravo. Ciência e Agrotecnologia, Lavras, v.33, n.6, p.1560-1568, 2009.

PRADO, R.M.; VALE, D.W.; ROMUALDO, L.M. Fósforo na nutrição e produção de mudas de maracujazeiro. Acta Scientiarum. Agronomy, Maringá, v.27, n.3, p.493-498, 2005.

REZENDE, C.F.A.; FERNANDES, E.P.; SILVA, M.F.; LEANDRO W.M. Crescimento e acúmulo de nutrientes em mudas cítricas cultivadas em ambiente protegido. Bioscience Journal, Uberlândia, v.26, n.3, p.367-375, 2010.

ROZANE, D.E.; PARENT, L.E.; NATALE, W. Evolution of the predictive criteria for the tropical fruit tree nutritional status. Científica, Jaboticabal, v.44, n.1, p.102$112,2016$.

ROZANE, D.E.; PRADO, R.M.; NATALE, W.; BEUTLER, A.N.; SILVA, S.R.; BARBOSA, J.C. Nitrogênio, fósforo e potássio afetando a nutrição e produção de porta-enxerto de limoeiro citrumelo swingle. Revista Ceres, Viçosa, MG, v.54, n.315, p.422-429, 2007.

ROZANE, D.E.; PRADO, R.M.; NATALE, W.; FRANCO, C.F. Crescimento, teor e acúmulo de nutrientes em hipobiotos de caramboleiras, cultivados em diferentes soluções nutritivas. Revista Ceres, Viçosa, MG, v.58, n.3, p.366-372, 2011 a.

ROZANE, D.E.; PRADO, R.M.; NATALE, W.; ROMUALDO, L.M.; FRANCO, C.F. Caracterização biométrica e acúmulo de nutrientes em porta-enxertos de caramboleira cultivada em solução nutritiva. Revista Ciência Agronômica, Fortaleza, v.44, n.3, p.426-436, 2013. 
ROZANE, D.E.; PRADO, R.M.; NATALE, W.; ROMUALDO, L.M.; SOUZA, H.A.; SILVA, S.H.M.G. Produção de mudas de caramboleiras 'B-10' e 'Golden Star': II - Marcha de absorção e acúmulo de nutrientes. Revista Brasileira de Fruticultura, Jaboticabal, v.33, n.4, p.1308-1321, 2011 b.

ROZANE, D.E.; PRADO, R.M; NATALE, W.; BEUTLER, A.N.; SILVA, S.R.; BARBOSA, J.C. Efeito das doses de nitrogênio, fósforo e potássio na nutrição e na produção do porta-enxerto de limoeiro cravo. Acta Scientiarum. Agronomy, Maringá, v.31, n.2, p.255-260, 2009a.

ROZANE, D.E.; SOUZA, H.A.; PRADO, R.M.; NATALE, W.; FRANCO, C.F.; LEAL, R.M. Influência do cultivar, do tipo de folha e do tempo de cultivo na medida indireta da clorofila (SPAD) em mudas de goiabeira. Ciência e Agrotecnologia, Lavras, v.33, n.6, p.15381543, 2009b.

RUSCHEL, J.; CARMELLO, Q.A.C.; BERNARDI, A.C.C.; CARVALHO, S.A.; MATTOS JÚNIOR, D. Leaf nutrient contents of rangpur lime rootstock as affected by $\mathrm{N}, \mathrm{P}, \mathrm{K}, \mathrm{Ca}$ and $\mathrm{S}$ fertilization. Scientia Agricola, Piracicaba, v.61, n.5, p.501-506, 2004.

SCHÄFER, G.; SOUZA, P.V.D.; KOLLER, O.C.; SCHWARZ, S.F. Physical and chemical properties of substrates to cultivate seedling of citrus rootstocks.

Communications in Soil Science and Plant Analysis, New York, v.39, n.7-8, p.1067-1079, 2008.

SERRANO, L.A.L.; CATTANEO, L.F.; FERREGUETTI, G.A. Adubo de liberação lenta na produção de mudas de mamoeiro. Revista Brasileira de Fruticultura, Jaboticabal, v.32, n.3, p.874-883, 2010.
SILVA, E.B.; FARNEZI, M.M.M. Limitações nutricionais para o crescimento de mudas de graviola em casa de vegetação em Latossolo vermelho distrófico do Norte de Minas Gerais. Bioscience Journal, Uberlândia, v.25, n.6, p.52-58, 2009.

SILVA-MATOS, R.R.S.; SILVA JUNIOR, G.B.; MARQUES, A.S.; MONTEIRO, M.L.; CAVALCANTE, Í.H.L.; OSAJIMA, J.A. New organic substrates and boron fertilizing for production of yellow passion fruit seedlings. Archives of Agronomy and Soil Science, Berlin, v.62, n.3, 445-455, 2016.

SOUZA, H.A.; ROZANE, D.E.; AMORIM, D.A.; DIAS, M.J.T.; MODESTO, V.C.; NATALE, W. Assessment of nutritional status of guava seedlings using preliminary DRIS norms and sufficiency ranges. Journal of Plant Nutrition, New York, v.38, n.10, p.1611-1618, 2015.

TECCHIO, M.A.; LEONEL, S; LIMA.C.P.; VILLAS BOAS, R.L.; ALMEIDA, E.L.P.; CORREA, J.C. Crescimento e acúmulo de nutrientes no porta-enxerto citrumelo 'Swingle', cultivado em substrato. Bioscience Journal, Uberlândia, v.22, n.1, p.37-44, 2006.

VICHIATO, M.; CARVALHO, J.G.; VICHIATO, M.R.M.; SILVA, C.R.R. Interações fósforo-magnésio em mudas de mamoeiros Tainung $n^{\circ} .1$ e Improved Sunrise Solo 72/12. Ciência e Agrotecnologia, Lavras, v.33, n.5, p.1265-1271, 2009.

ZAMBROSI, F.C.B.; MATTOS JUNIOR, D.; QUAGGIO, J.A.; CANTARELLA, H.; BOARETTO, R.M. Phosphorus uptake by young citrus trees in Low-P soil depends on rootstock varieties and nutrient management. Communications in Soil Science and Plant Analysis, New York, v.44, n.14, p.2107-2117, 2013. 